\title{
Serum acute phase proteins in cows with SARA (Subacute Ruminal Acidosis) suspect
}

[Proteínas séricas de fase aguda em vacas com suspeita de SARA (Subacute Ruminal Acidosis)]

\author{
C. Cannizzo ${ }^{1}$, M. Gianesella ${ }^{1}$, E. Giudice $e^{2}$, V. Messina ${ }^{3}$, G. Piccione ${ }^{3^{*}}$, M. Morgante ${ }^{1}$ \\ ${ }^{1}$ Department of Veterinary Clinical Sciences, University of Padua, \\ Viale dell'Università 16, 35020, Legnaro (PD), Italy \\ ${ }^{2}$ Department of Veterinary Public Health, University of Messina, \\ Polo Universitario dell'Annunziata, 98168, Messina (ME), Italy \\ ${ }^{3}$ Department of Experimental Sciences and Applied Biotechnology, University of Messina, \\ Polo Universitario dell'Annunziata, 98168, Messina (ME), Italy
}

\begin{abstract}
The aim of this study was to evaluate the variations of Acute Phase Proteins (APPs) and other blood constituents during the onset of the sub-acute ruminal acidosis (SARA) pathological status. A total of 108 cows from 12 dairy herds were randomly selected and divided into three Groups of 36 animals each. All animals were subjected to a rumenocentesis. Group A was composed by subjects with a rumen $\mathrm{pH}>5.8$, Group B was composed by subjects with a rumen $\mathrm{pH} \leq 5.5 \leq 5.8$ and Group $\mathrm{C}$ was composed by subjects with a rumen $\mathrm{pH}<5.5$. Blood samples were collected by jugular venipuncture and Haptoglobin $(\mathrm{Hp})$, Serum Amyloid A (SAA), Total Proteins, Albumin and White Blood Cells (WBC) were determined. Oneway ANOVA showed a statistical significance on Rumen $\mathrm{pH}, \mathrm{Hp}$, SAA. SARA seems not stimulate the APPs production from liver.
\end{abstract}

Keywords: acute phase protein, dairy cow, haptoglobin, serum amyloid A, SARA

\section{RESUMO}

O objetivo deste estudo foi avaliar as variações de Proteínas de Fase Aguda (APPs) e outros constituintes sanguíneos durante o início do status patológico de sub-acute ruminal acidosis (SARA). $O$ total de 108 vacas de 12 rebanhos leiteiros foram aleatoriamente selecionados e divididos em três grupos com 36 animais cada. Todos os animais foram submetidos a ruminocentesis. O Grupo A foi composto por sujeitos com rumen $\mathrm{pH}>5.8$, o Grupo $B$ foi composto por sujeitos com rumen $p H \leq 5.5 \leq 5.8$ e o Grupo $C$ foi composto por sujeitos com rumen $\mathrm{pH}<5.5$. Amostras sanguíneas foram coletas por punção venosa jugular e Haptoglobin (Hp), Serum Amyloid A (SAA), Proteínas totais, Albumin e células brancas do sangue (WBC) foram determinadas. ANOVA em via única mostrou significância estatística em Rumen pH, Hp, SAA. SARA não parece estimular a produção de APPs pelo fígado.

Palavras-chave: proteína de fase aguda, gado leiteiro, haptoglobin, serum amyloid A, SARA

\section{INTRODUCTION}

In recent years an increasing interest was addressed to the animal welfare of dairy cows. The sub-acute ruminal acidosis (SARA) is one of the most frequent and insidious pathology in dairy cattle. This is due to an unbalance between

Recebido em 24 de maio de 2010

Aceito em 15 de abril de 2011

*Autor para correspondência (corresponding author)

E-mail: giuseppe.piccione@unime.it the production of short chain fatty acids (SCFA) in the rumen and their absorption and neutralization (Enemark et al., 2004). This unbalance is directly dependent on an increase of the easily digestible carbohydrates in the feed ration, with an increased production of butyric acid, despite the starch that instead leads to a production of propionic acid as final result of the 
decomposition of cellulose (Garrett et al., 1999; Enemark et al., 2004). The diagnosis of SARA in a group or in a dairy herd is possible by measuring the rumen $\mathrm{pH}$ in a subsample of cows (Enemark et al., 2004). Clinical signs are usually absent or, when present, tend to be ambiguous (Enenmark et al., 2004). The symptoms of SARA are largely variable, but often the first pathological event and the most common is a reduction of appetite and rumination (Ghozo et al., 2005). Infection, inflammation, trauma and tumours can induce an acute phase reaction, in which the production of various acute phase proteins (APPs) by the liver is increased and these proteins are secreted into the blood (Kujala et al., 2010). An elevation of Haptoglobin (Hp) and Serum Amyloid A (SAA) was previously suggested as a useful parameter for controlling SARA (Enemark et al., 2008; Mohebbi et al., 2010). It has been suggested that low rumen $\mathrm{pH}$ could result in death and lysis of gram-negative bacteria that are in the rumen and hence increase free endotoxins in the rumen (Nagaraja et al., 1978; Andersen et al., 1994). The acidic rumen environment, changes in osmotic pressure, and ruminal LPS may render the rumen epithelium susceptible to injury (Brent, 1976; Enemark et al., 2002; Kleen et al., 2003), resulting in the translocation of rumen endotoxin into the bloodstream (Kleen et al., 2003). Ruminal endotoxin was implicated in the etiology of multiple metabolic disorders (Andersen, 2003; Ametaj et al., 2005). The presence of LPS in the bloodstream results in the production of multiple proinflammatory cytokines, reactive oxygen and nitrogen intermediates, and bioactive lipids, which affect the host's metabolic response to inflammation (Baumann and Gauldie, 1994). Hp is a system of globulins circulating bound to haemoglobin which in response to various stimuli releases haptoglobin intravascularly from erythrocytes (Maes et al, 1995). SAA, instead, is an apolipoprotein which has an important role during inflammation which is still not well understood and is one of the most reactive during the acute phase response both in humans and in animals (Badolato et al., 1994; Murata et al, 2004; Baghshani et al., 2010; Deguchi et al., 2010). Some of these functions include detoxification of endotoxins, inhibition of $\mathrm{T}$ lymphocyte adhesion and a down regulation of the inflammatory process (Murata et al, 2004). In cows the APPs are elevated in stress conditions such as delivery, parturition and particular diseases as in the fatty liver syndrome (Murata $e t$ al 2004; Huzzey et al., 2009). The significance of the individual differences in the APP response remains to be elucidated. In cattle, SAA is generally perceived as an indicator of acute inflammation, whereas haptoglobin is more slowly reacting and thus reflects the presence of chronic inflammatory conditions (Alsemgeest et al., 1994; Horadagoda et al., 1999).

In the past, few researchers studied the relationship between SARA and the serum acute phase proteins (Khafipour et al., 2009; Ghozo et al., 2005). Based on these considerations, the aim of this study was to evaluate the variations of APPs, and some blood parameters in relation to the onset of this pathological status.

\section{MATERIALS AND METHODS}

12 Italian intensive dairy herds were selected from different areas throughout northern Italy, some of which were considered potentially at high risk of SARA. All herds had a high average milk production (about 10000kg per year); the dairy cows were housed in free stalls and, in the early part of their lactation, used a total mixed ration (TMR) and adopted "steaming up" in the final part of the dry period as standard farming practice. 108 cows were randomly selected from all farms and were divided into three Groups of 36 animals each, based on ruminal $\mathrm{pH}$. All animals were Holstein breed in the first 60 days of lactation, and were healthy at clinical examination. Table 1 shows the chemical composition analysis of the diet administered during the study. The Body Condition Score (BCS) average values were $3.03 \pm 0.07$, in a 1 to 5 scale, according with the procedure of Edmonson (Edmonson et al.,1989). All cows which participated in the study were subjected to a rumenocentesis, using a $13 \mathrm{G}$ 105-mm needle (Intranule PP, Vygon, France), the most commonly used technique which provides accurate results (Garrett et al., 1999; Duffield et al., 2004; Morgante et al., 2007). The time of sampling was between 4 and 6 hours post TMR distribution as recommended by Morgante et al.(2007). An area in the left flank of $20 \times 20 \mathrm{~cm}$, $20 \mathrm{~cm}$ caudal to the last costae, and on the level of the top of the stifle joint was prepared with an aseptic technique by disinfection with ethanol and iodine. The farmer was instructed to restrain the dairy cows by means of a tail grip and the 
needle was introduced into the rumen by a veterinary surgeon. The rumen $\mathrm{pH}$ was immediately determined by means of a portable pHmeter (Piccolo, Hanna Instruments). All animals were classified into three different Groups according to the acidosis risk, depending on the rumen $\mathrm{pH}$. Group A was composed by subjects with a rumen $\mathrm{pH}>5.8$, Group B was composed by subjects with a rumen $\mathrm{pH} \leq 5.5 \leq 5.8$ and Group $\mathrm{C}$ was composed by subjects with a rumen $\mathrm{pH}<5.5$.

Table 1. Mean values of the chemical composition of the diet administered to 108 cows from 20 dairy herds

\begin{tabular}{lc}
\multicolumn{1}{c}{ Parameters } & Mean \pm SD \\
\hline Crude protein & $15.21 \pm 1.06$ \\
Ethereal extract & $4.52 \pm 0.43$ \\
Ash & $7.48 \pm 0.85$ \\
NDF & $35.30 \pm 1.83$ \\
NSC & $37.46 \pm 2.47$ \\
Digestible dry matter (\%ss) & $65.48 \pm 1.85$ \\
ADF & $20.58 \pm 1.66$ \\
Starch & $22.87 \pm 1.97$ \\
Calcium & $1.00 \pm 0.05$ \\
Phosphorus & $0.45 \pm 0.01$ \\
Magnesium & $0.33 \pm 0.02$ \\
Sodium & $0.58 \pm 0.05$ \\
Potassium & $1.45 \pm 0.10$ \\
Chlorine & $0.32 \pm 0.09$ \\
Anions/Cations (meq) & $41.78 \pm 2.09$ \\
NDF/NSC & $0.94 \pm 0.10$ \\
NSC/NDF & $1.06 \pm 0.11$ \\
NDF/Proteins & $2.33 \pm 0.22$ \\
Starch/Proteins & $1.50 \pm 0.14$ \\
\hline
\end{tabular}

Blood samples were collected through jugular venipuncture before rumenocentesis (to avoid stress effect on blood parameters) under aseptic conditions and placed in tubes containing $1.2 \mathrm{mg}$ anhydrous salt of ethylenediamine tetraacetic acid $\left(\mathrm{K}_{3}\right.$ EDTA) per $\mathrm{ml}$ of blood. A white blood cells (WBC) count was performed on collected blood samples through an automatic analyser for haematology (Abbott Cell Dyn 3500 - Abbott Diagnostic Division, CA; software 6.1)). The hematochemical profile was determined on plasma obtained from blood collected in tubes with lithium-heparin and the total proteins and albumin were measured through the Boehringer Mannheim/Hitachi 911 automated chemistry analyser (Roche, Basel, Switzerland) The $\mathrm{Hp}$ determination was performed on serum, at the Reactivlab ltd (Glasgow University), through an automated biochemical assay validated by Eckersall et al (1999) which measures the increase in absorbance. The principle of this test is based on the peroxidase activity of haemoglobin, inhibited at low $\mathrm{pH}$. The Haptoglobin binds free haemoglobin and preserves, even at low $\mathrm{pH}$, the peroxidase activity, which is therefore directly proportional to the level of haptoglobin in the sample.

The concentration of SAA in bovine serum was quantified by using a commercial ELISA obtained from Tridelta Development Ltd. (Dublin, Ireland), according to the manufacturer's instructions.

Total proteins and Albumin were determined from an aliquot of blood stored into vacutainer tubes without anticoagulant, through an automated analyser (Boehringer Mannheim/ HITACHI 911, Roche, Basel, Svizzera).

One-way Analysis of Variance (ANOVA) was applied to compare all Groups. Bonferroni's test was applied for post hoc comparison. A $P$ value $<0.05$ was considered statistically significant. Correlation and linear regression between Rumen $\mathrm{pH}$ and other parameters were performed. All data was analysed using Statistica 7 software (Statsoft Inc.).

\section{RESULTS}

Table 2 shows mean values $( \pm \mathrm{SD})$ of all studied parameters with the statistical significances, expressed in their conventional units of measurement. 
Table 2. Mean values $( \pm \mathrm{SD})$ of the parameters analyzed, expressed in their units of measurements, with the statistical significance, from 108 dairy cows, divided into three groups by the rumen $\mathrm{pH}$ range: Group A (rumen $\mathrm{pH}>5.8$ ), Group B (rumen $\mathrm{pH} \leq 5.5 \leq 5.8$ ) and Group $\mathrm{C}$ (rumen $\mathrm{pH}<5.5$ )

\begin{tabular}{lcccc}
\hline \multicolumn{4}{c}{ Experimental Conditions } & \\
\hline Parameters & Group A & Group B & Group C & $\begin{array}{c}\text { Reference } \\
\text { Values }\end{array}$ \\
Rumen pH & $6.20 \pm 0.39$ & $5.77 \pm 0.35$ & $5.57 \pm 0.31^{*}$ & $6.8-5.8$ \\
Haptoglobin $(\mathrm{g} / \mathrm{L})$ & $0.24 \pm 0.04$ & $0.11 \pm 0.08^{*}$ & $0.12 \pm 0.07^{*}$ & $0.08 \pm 0.03$ \\
Serum Amyloid A( $\mu \mathrm{g} / \mathrm{ml})$ & $46.09 \pm 15.72$ & $107.13 \pm 35.51^{*}$ & $67.50 \pm 15.22^{*}$ & $4.50 \pm 0.18$ \\
Total Proteins $(\mathrm{g} / \mathrm{dL})$ & $78.51 \pm 7.40$ & $82.29 \pm 6.93$ & $80.29 \pm 8.99$ & $67.4-74.6$ \\
Albumin $(\%)$ & $34.63 \pm 3.12$ & $36.00 \pm 3.73$ & $36.71 \pm 3.96$ & $30.30-35.50$ \\
White Blood Cells $\left(10^{3} / \mathrm{ml}\right)$ & $7.33 \pm 1.39$ & $7.34 \pm 1.78$ & $6.77 \pm 1.08$ & $4-12$ \\
\hline
\end{tabular}

Statistical significances:

${ }^{*}$ Vs Group A $(\mathrm{P}<0.001)$

- Vs Group B $(\mathrm{P}<0.001)$

One way ANOVA showed a statistical significance on Rumen $\mathrm{pH} \quad(\mathrm{P}<0.001$; $\left.\mathrm{F}_{(2 ; 107)}=13.84\right), \quad \mathrm{Hp} \quad\left(\mathrm{P}<0.001 ; \quad \mathrm{F}_{(2 ; 107)}=43.33\right)$, SAA $\left(\mathrm{P}<0.001 ; \mathrm{F}_{(2 ; 107)}=59.54\right)$. ANOVA showed no statistical significances on total proteins. All the results are graphically presented in Figure 1. No statistical significances emerged from the analysis of the correlation and the linear regression.

\section{DISCUSSIONS}

In contrast to monogastric mammals, about $50 \%$ of healthy cattle show an undetectable Hp level in plasma, and in the remaining healthy animals the concentrations reach $0.1 \mathrm{~g} / \mathrm{L}$ (Jawor et al., 2010). In our study the Hp levels were higher in Group A, while we observed lower and similar values in the other groups. During an inflammatory event, the $\mathrm{Hp}$ rises rapidly and decreases in the following days, until returning to normal levels in about 10 days (Jawor et al., 2010). High levels of $\mathrm{Hp}$ can be detected not only in ill subjects, but also in stress conditions (Murata et al., 2004; Carroll et al., 2009). In fact, stress has a role in activating latent infections resulting in acute phase response (Chan et al., 2004) and we know that acute phase proteins could also be released in a stressful event: it is widely accepted that, in humans and experimental animals, physical and psychological stress elevates plasma IL-6 and APPs levels (Deak et al., 1997; Nukina et al., 2001). There is also evidence in cattle that physical stress can induce Acute Phase
Response(APR) (Murata and Miyamoto, 1993; Alsemgeest et al., 1995; Lomborg et al., 2008). The activation of the hypothalamic-pituitaryadrenal (HPA) axis by stress signals may be a trigger of systemic or local (intra-pituitary) cytokine production, thereby augmenting hepatic APP synthesis and release into the bloodstream (Murata et al., 2004). In ruminants, the basal Hp values oscillate between 0.08 and $0.30 \mathrm{~g} / \mathrm{L}$ (Chan et al., 2004; Nowroozsi-Asl et al., 2008; Baghshani et al., 2010). The hp values we found in this trial were within the physiological range for $\mathrm{Hp}$, and did not reach the serum levels found in severe diseases, just as in the retained placenta or a post partum metritis, where $1.13 \mathrm{~g} / \mathrm{L}$ of $\mathrm{Hp}$ are expected (Chan et al., 2004). Both the groups at risk of SARA (B and C) showed lower values than the basal and this suggests that this metabolic condition does not affect the $\mathrm{Hp}$ production from liver. This situation is very different from what is described in literature, probably because in an experimental condition, grain-induced SARA determines a defined inflammatory status more comparable to an acute/inflammatory situation, while in field conditions this does not happen. Moreover, some authors showed a similar result demonstrating that SARA is a metabolic pathology that does not stimulate the immune response (Khafipour et al., 2009). Regarding the higher levels of $\mathrm{Hp}$ in group A, we could probably assist to a physiological-induced increase since this group had the lower days in milk average and haptoglobin has been cited as calving-inducted protein. 

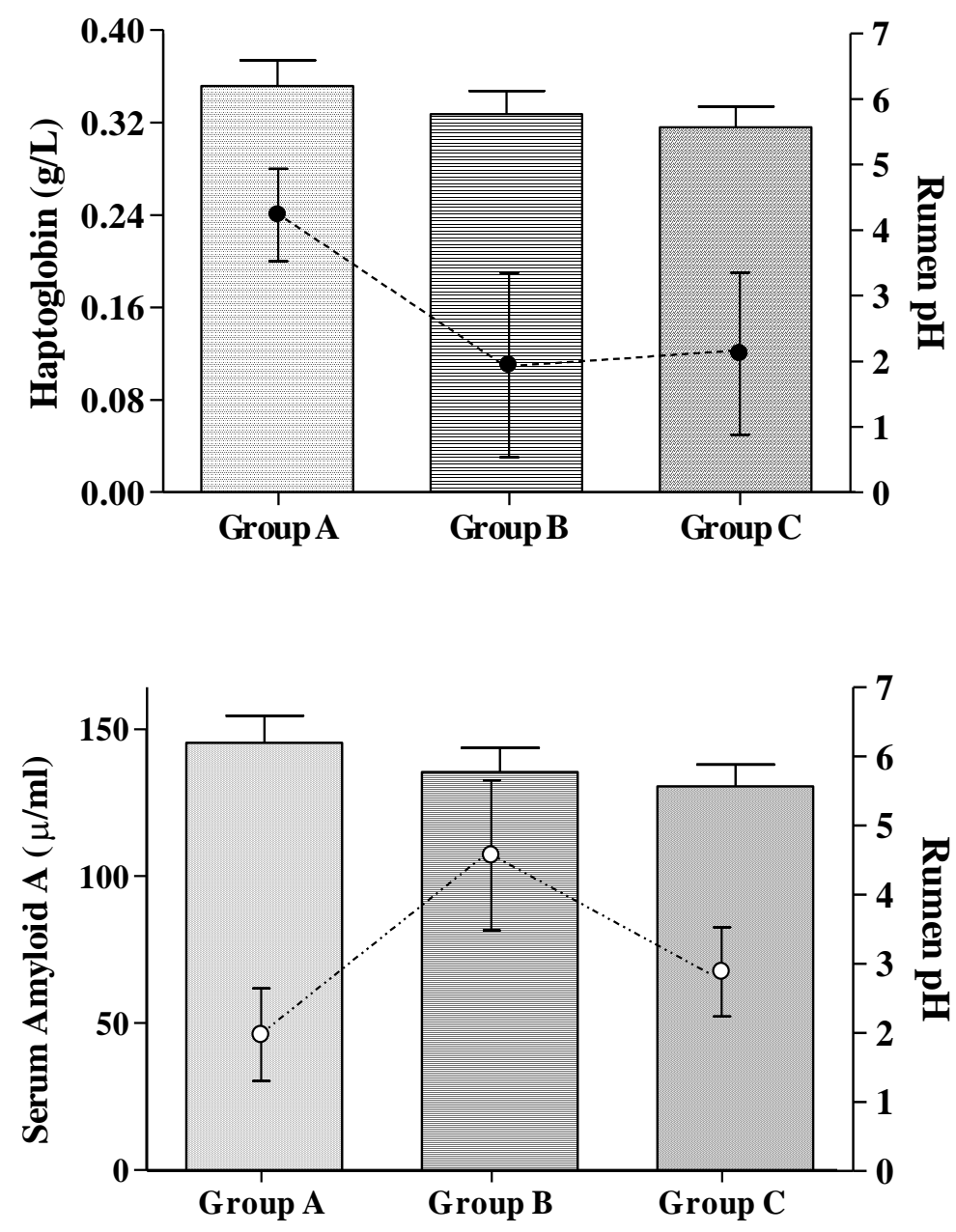

$\mathrm{b}$

Figure 1. Patterns of the Rumen pH, some Acute Phase Proteins (Haptoglobin(a) and Serum Amyloid $\mathrm{A}(\mathrm{b})$ ) in relation to the sub-acute ruminal acidosis (SARA), in 108 dairy cows, divided into three groups based on the rumen $\mathrm{pH}$ values: Group $\mathrm{A}(\mathrm{pH}>5.8)$, Group $\mathrm{B},(\mathrm{pH} \leq 5.5 \leq 5.8)$ and Group $\mathrm{C}(\mathrm{pH}<5.5)$.

SAA values found were higher than the mean values reported by other authors and had an opposite trend in relation to the values of $\mathrm{Hp}$ (Nazifi et al., 2009). Elevated SAA serum levels can be found following inflammation and also under conditions unrelated to inflammation, such as physical stress or parturition (Baghshani et al., 2010; Murata et al., 2004). Group B, composed by medium risk acidosis cows with a rumen $\mathrm{pH}$ mean value of 5.75 , showed the most elevated SAA level, while Group C, composed by high risk cows, had a SAA level lower than Group B. Positive acute phase response was reportedly associated to a change in metabolism (Gruys et al., 2005). Abrupt SARA induction in heifers and
SARA induced by gradual adaptation from a forage based diet to a concentrate diet was associated to an increase of SAA in many trials, but some authors indicated that while graininduced SARA has reportedly increased APP concentration in blood, SARA induced by reducing fiber particle size did not (Mulligan and Doherty, 2008) and this second situation is probably more similar to the field situation in North Italy. The cows used in our research were animals subjected to an intensive metabolic activity, including calf production. We hypothesized that, in any case, our results are not related to SARA, since the higher serum level does not correspond to the lower rumen $\mathrm{pH}$ 
value, and elevated SAA serum levels are found in cows at parturition and in those with mastitis (Alsemgeest et al., 1994; Murata et al., 2004, Safi et al., 2009). Moreover, since Hp decreases in group $\mathrm{B}$ and $\mathrm{C}$ and albumin (that is a negative APP) lightly increased at the same time, we could exclude an inflammatory status or an acute phase response.

\section{CONCLUSIONS}

The situation we found in field conditions is very different from what many authors described inducing SARA with barley grain and from studies in which LPS were infused directly regardless of sequelae before they are supposed to translocate in portal vein. It is still unclear by which mechanism LPS, when it passes a ruminal barrier, can pass portal circulation and hepatic barrier and stimulate an APR, since LPS can be detossified by the liver before reaching general circulation (Andersen et al., 2003) but many receptors for cytochines are present in kupfer cells (Bode e Heinrich, 2001) and then the first proinflammatory citochines could be released before the detossification starts.

Our results seem to indicate that SARA does not stimulate the immune response, even if the subjects in our study were in lactation and few cows were in the SARA threshold. We must consider also that clinical signs attributed to SARA become manifest after a certain delay to the initial insult: since we don't know if cows that we diagnosed with SARA are having problems afterwards and if normal cows have had subclinical problems before, it is difficult to relate APP variations to other clinical signs or more difficult to subclinical signs. We can then suggest that SARA should be considered a group-disease, since individual variations can disturb the diagnosis and it is necessary to exclude individual effect using a statistically significant number of animals.

Further investigation should be done to assess the influence of lower rumen $\mathrm{pH}$ values on the immune response, and it would be interesting to investigate more on causes and effects of SARA to understand if this fermentative disturb could be the consequence of stressful situations. If the main cause to develop SARA was linked to welfare, we could easily connect SARA to structures and management that could determine lameness or other problems and explain many related pathologies that probably are not caused by SARA, but are the cause.

\section{REFERENCES}

ALSEEMGEST, S.P.M.; KALSBEEK, H.C.; WENSING, T.H. et al. Concentrations of serum amyloid-A (SAA) and haptoglobin (Hp) as parameters of inflammatory diseases in cattle. Vet. Q., v.1, p.21-23, 1994.

ALSEMGEEST, S.P.; LAMBOOY, I.E.; WIERENGA, H.K. et al. Influence of physical stress on the plasma concentration of serum amyloid-A (SAA) and haptoglobin (Hp) in calves. Vet. Q. v.17, p.9-12, 1995.

AMETAJ, B.N.; BRADFORD, B.J.; BOBE, G. et al. Strong relationship between mediators of the acute phase response and fatty liver in dairy cows. Can. J. Anim. Sci., v.85, p.165-175, 2005.

ANDERSEN, P.H.; BERGELIN, B.; CHRISTENSEN, K.A. Effect of feeding regimen on concentration of free endotoxin in ruminal fluid of cattle. J. Anim. Sci., v.72, p.487-491, 1994.

ANDERSEN, P.H. Bovine endotoxicosis: some aspects of relevance to production diseases. Acta Vet. Scand., v.98, suppl., p.141-155, 2003.

BAGHSHANI, H.; NAZIFI, S.; SAEB, M. et al. Influence of road transportation on plasma concentrations of acute phase proteins, including fibrinogen, haptoglobin, serum Amyloid A and ceruloplasmin, in dromedary camels (Camelus dromedaries). Comp. Clin. Pathol., v.19, p.193-198, 2010.

BADOLATO, R.; WANG, J.M.; MURPHY, W.J. et al. Serum Amyloid A is a chemoattractant: induction of migration, adhesion, and tissue infiltration of monocytes and polymorphonuclear leukocytes. J. Exp. Med., v.180., p.203, 1994.

BAUMANN, H.; GAULDIE, J. The acute phase response. Immunol. Today, v.15, p.74-80, 1994.

BODE, J.G.; HEINRICH, P.C. Interleukin-6 signaling during the acute-phase response of the liver. In:. ARIAS, I.M.; BOYER, J.L.; CHISARI, F.V. et al. The liver, biology and pathobiology. (Eds). Lippincott Williams and Wilkins, Philadelphia, PA, p.565-580, 2001.

BRENT, B.E. Relationship of acidosis to other feedlot ailments. J. Anim. Sci., v.43, p.930-935, 1976. 
CARROLL, J.A.; ARTHINGTON, J.D.; CHASE, C.C. Early weaning alters the acute phase reaction to an endotoxins challenge in beef calves. J. Anim. Sci., v.87, p.4167-4172, 2009.

CHAN, J.P.W.; CHU, C.C.; FUNG, H.P. et al. Serum haptoglobin concentration in cattle. J. Vet. Med. Sci., v.66, p.43-46, 2004.

DEAK, T.; MERIWETHER, J.L.; FLESHNER, M. et al. Evidence that brief stress may induce the acute phase response in rats. Am. J. Physiol., v.273, p.1998-2004, 1997.

DEGUCHI, M.; SHINJO, R.; YOSHIOKA, Y. et al. The usefulness of serum amyloid $\mathrm{A}$ as postoperative inflammatory marker after posterior lumbar interbody fusion. J. Bone Jt Surg. Br., v.92, p.555-559, 2010.

DUFFIELD, T.; PLAIZIER, J.C.; FAIRFIELD, A. et al. Comparison of techniques for measurement of rumen $\mathrm{pH}$ in lactating dairy cows. J. Dairy Sci., v.87, p.59-66, 2004.

ECKERSALL, P.D.; DUTHIE, S.; TOUSSAINT, M.J. et al. Standardization for diagnostic assays for animal acute phase proteins. Adv. Vet. Med., v.41, p.643-655, 1999.

EDMONSON, A.J.; LEAN, I.J.; WEAVER, L.D. et al. A body condition scoring chart for Holstein Dairy Cows. J. Dairy Sci., v.72, p.68-78, 1989.

ENEMARK, J.M.; JØRGENSEN, R.J.; ENEMARK, P. Rumen acidosis with special emphasis on diagnostic aspects of subclinical rumen acidosis: a review. Vet. Zootec., v.20, p.1629, 2002.

ENEMARK, J.M.D.; JORGENSEN, R.J.; KRISTENSEN, N.B. An evaluation of parameters for the detection of subclinical rumen acidosis in dairy herds. Vet. Res. Commun., v.28, p.687-709, 2004.

ENEMARK, J.M.D. The monitoring prevention and treatment of subacute ruminal acidosis (SARA): a review. Vet. J., v.176, p.32-43, 2008.

GARRETT, E.F.; PERREIRA, M.N.; NORDLUND, K.V. Diagnostic methods for the detection of subacute ruminal acidosis in dairy cows. J. Dairy Sci., v.82, p.1170-1178, 1999.

GHOZO, G.N.; PLAIZIER, J.C.; KRAUSE, D.O. et al. Subacute ruminal acidosis induces lipopolisaccharide endotoxins release and triggers an inflammatory response. J. Dairy Sci., v.88, p.1399-1403, 2005.
GRUYS, E.; TOUSSANT, M.J.M.; NIEWOLD, T.A. et al. Acute phase reaction and acute phase proteins. J. Zheijang Univ. SCI., v.6, p.1045-1056, 2005.

JAWOR, P.; STEFANIAK, T.; KATNIKPRASTOWSKA, I. Determination of Haptoglobin in bovine serum using polyclonal and monoclonal Anti-human Haptoglobin antibodies. Acta Vet. Brno., v. 79, p. 105-112, 2010.

HORADAGODA, N.U.; KNOX, K.M.G; GIBBS, H.A. et al. Acute phase proteins in cattle: Discrimination between acute and chronic inflammation. Vet. Rec., v.144, p.437-441, 1999.

HUZZEY, J.M.; DUFFIELD, T.F.; LE BLANC, S:J. et al., Short communication: Haptoglobin as an early indicator of metritis. J. Dairy Sci., v.92, p.621-625, 2009.

KHAFIPOUR, E.; KRAUSE, D.O.; PLAIZIER, J.C. Alfalfa pellet-induced subacute ruminal acidosis in dairy cows increases bacterial endotoxin in the rumen without causing inflammation. $J$. Dairy Sci., v.92, p.1712-1724, 2009.

KLEEN, J.L.; HOOIJER, G.A.; REHAGE, J. et al. Subacute ruminal acidosis (SARA): A review. $J$. Vet. Med. A Physiol. Pathol. Clin. Med., v.50, p.406-414, 2003.

KUJALA, M.; ORRO, T.; SOVERI, T. Serum acute phase proteins as a marker of inflammation in dairy cattle with hoof diseases. Vet. Rec., v.166, p.240-241, 2010 .

LOMBORG, S.R.; NIELSEN, L.R.; HEEGAARD, P.M.H. et al. Acute phase proteins in cattle after exposure to complex stress. Vet. Res. Commun., v.32, p.575-582, 2008.

MAES, M.; COOREMAN, W.; DELANGHE, J. et al. Components of biological variation in plasma haptoglobin: relationships to plasma fibrinogen and immune variables, including interleukin-6 and its receptor. Clin. Chim. Acta., v.239, p.23-25, 1995.

MOHEBBI, M.; SAJEDIANFARD, J.; NAZIFI, S.; SAMIMI, A.S. Changes of serum amyloid A, haptoglobin, ceruloplasmin, fibrinogen, and lipidassociated sialic acid in sheep fed high grain rations with altered digestive functions. Comp. Clin. Pathol., v.19, p.541-546, 2010.

MORGANTE, M.; STELLETTA, C.; BERZAGHI, P. et al. Subacute rumen acidosis in lactating cows: an investigation in intensive Italian dairy herds. $J$. Anim. Physiol. Anim. Nutr., v.91, p.226-234, 2007. 
MULLIGAN, F.J.; DOHERTY, M.L. Production diseases of the transition cow. Vet. J, v.176, p.3-9, 2008.

MURATA, H.; MIYAMOTO, T. Bovine haptoglobin as a possible immunomodulator in the sera of transported calves. Br. Vet. J., v.149, p.277283, 1993.

MURATA, H.; SHIMADA, N.; YOSHIOKA, M. Current research on acute phase proteins in veterinary diagnosis: an overview. Vet. J., v.168, p.28-40, 2004.

NAZIFI, S.; RAZAVI, S.M.; ESMAILNEJAD, Z.; GHEISARI, H. Study on acute phase proteins (haptoglobin, serum amyloid A, fibrinogen and ceruloplasmin) changes and their diagnostic values in bovine tropical theileriosis. Parasitol. Res., v.105, p.41-46, 2009.
NAGARAJA, T.G.; BARTLEY, E.E.; FINA, L.R.; ANTHONY, H.D. Relationship of rumen gramnegative bacteria and free endotoxin to lactic acidosis in cattle. J. Anim. Sci., v.47, p.1329-1336, 1978.

NOWROOZI-ASL, A.; NAZIFI, S.; BAHARI, A. Determination of serum haptoglobin reference value in clinically healthy Iranian fat-tailed sheep. Iran. J. Vet. Res., v.9, p.171-173, 2008.

NUKINA, H.; SUDO, N.; AIBA, Y. et al. Restraint stress elevates the plasma interleukin-6 levels in germ-free mice. J. Neuroimmunol., v.115, p.46-52, 2001.

SAFI, S.; KHOSHVAGHTI, A.; JAFARZADEH, S.R. et al. Acute phase proteins in the diagnosis of bovine subclinical mastitis. Vet. Clin. Pathol., v.38, p.471-476, 2009. 